\title{
THE IMPACT OF THE VIRTUAL FITTING ROOM ON E-COMMERCE
}

\author{
Nada Marzouk \\ Digital Enterprise Management, HBA, University of Toronto,2014
}

\author{
A Major Research Project presented to Ryerson University \\ in partial fulfillment of the \\ requirements for the degree of Master of Digital Media in the program of \\ Digital Media \\ Toronto, Ontario, Canada, 2018 \\ (C) Nada Marzouk, 2018
}




\section{Author's Declaration}

I hereby declare that I am the sole author of this MRP. This is a true copy of the MRP, including any required final revisions.

I authorize Ryerson University to lend this MRP to other institutions or individuals for the purpose of scholarly research.

I further authorize Ryerson University to reproduce this MRP by photocopying or by other means, in total or in part, at the request of other institutions or individuals for the purpose of scholarly research.

I understand that my MRP may be made electronically available to the public.

Nada Marzouk 


\author{
Abstract \\ The Impact Of The Virtual Fitting Room On E-commerce \\ Nada Marzouk \\ Master of Digital Media 2018 \\ Digital Media \\ Ryerson University
}

On a high level, this research project explores the impact of the Virtual Fitting Room ("VFR") technology on e-commerce. More specifically, this project is concerned with exploring the impact of the VFR technology in relation to online fashion sales. The central question this project has considered is: Does a virtual fitting room lead to an increase in 1) social media engagement and 2) product sales? VFR technology provides end users with an understanding of how a piece of clothing fits. This project oversaw the implementation of a series of interventions to measure the value of VFR. To test the premise of this research, six Egyptian fashion designers with an ineffective online presence were assigned to an e-commerce platform with VFR technology. To measure the impact of VFR, the researcher targeted three key audiences: 1) designers who only use social media, 2) designers who use social media and have a website, and 3) designers who use social media and have an e-commerce store with VFR. A benchmark for each of social media engagement, sales, and returns were provided by each designer.

Results demonstrated that the presence of VFR significantly increased curiosity, customer loyalty, and engagement, while reducing uncertainty about sizing. However, the data collected was not sufficient to prove a direct correlation between the conversion rate and sales. 


\section{Acknowledgements}

This project is the result of a collaborative effort by many individuals who have generously contributed their time and knowledge to this thesis.

I would especially like to acknowledge the support received from Dr. Sean Wise. His wealth of knowledge, expertise and endless support helped me grow on a personal and professional level.

In addition, I would like to acknowledge my colleagues and professors at the Digital Media program at Ryerson University for their continuous support throughout this process. 


\section{Table of Contents}

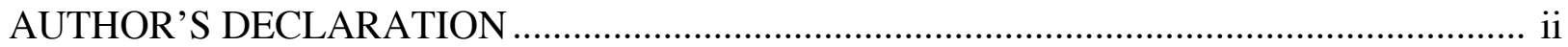

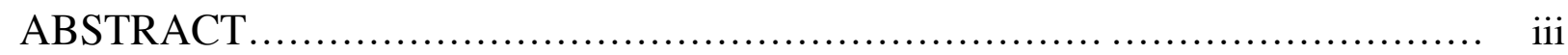

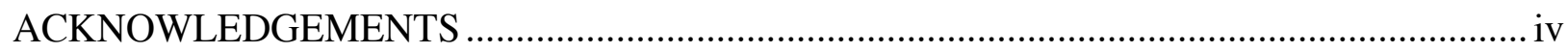

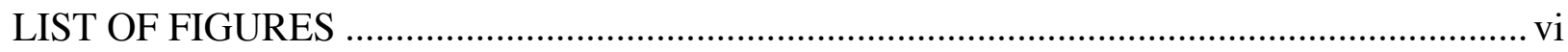

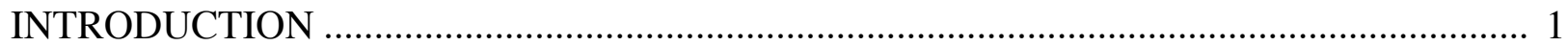

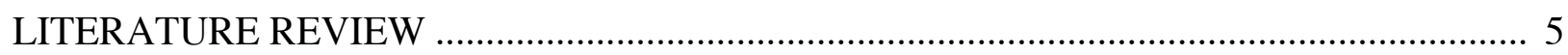

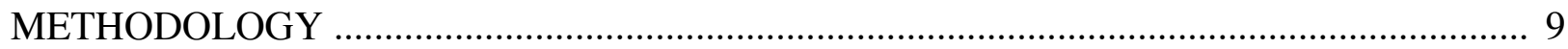

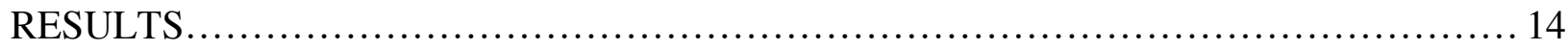

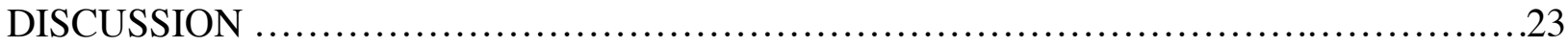

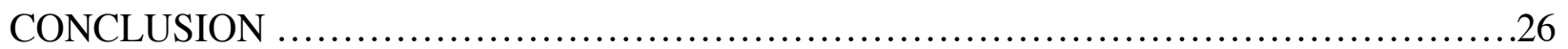

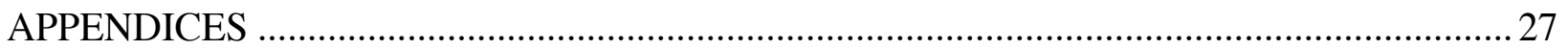

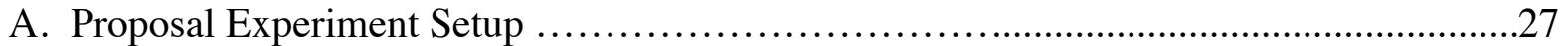

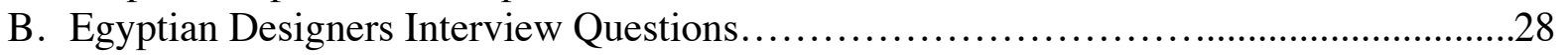

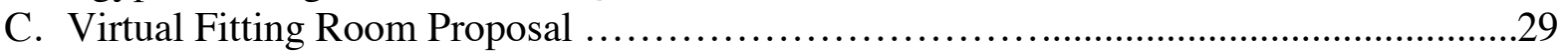

D. Early Adopters Survey Questions................................................

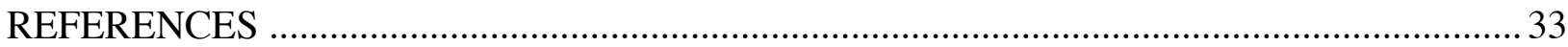




\section{List of Figures}

1. Metail Virtual Fitting Room .......................................................................... 3

2. Data Collected showcasing Engagement Tools used by Designers...................10

3. Type of Online Presence \& Engagement Tools used by Designers ..................10

4. Designer Screenshot - Farah Wagdy Instagram Page $\ldots \ldots \ldots \ldots \ldots \ldots \ldots \ldots \ldots \ldots \ldots \ldots \ldots \ldots$

5. Customizing Avatar Body Size \& Dimensions using Virtual Outfits LLC............12

6. Three Engagement Tools used in this project. ............................... 12

7. Virtual Outfits Closet displaying Egyptian designers' products.....................13

8. 3D Avatar wearing Garment made by Designer: Camicie .........................13

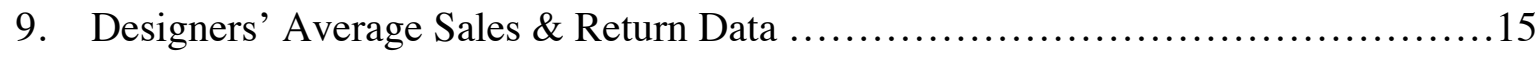

10. Table: Before VFR Implementation Designers Instagram Data................... 16

11. Chart: Before VFR Implementation Designers Instagram Data....................16

12. Instagram page created during duration of experiment..........................20

13. Table: Impact Reach vs Engagement Tools .................................22

14. Chart: Impact Reach after Virtual Fitting Room Implementation....................24

15. Virtual Outfits LLC, Monthly Avatar Try-on Report.............................20

16. Virtual Outfits LLC, Performance of Users Report............................21

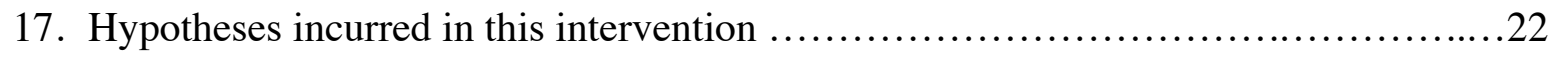

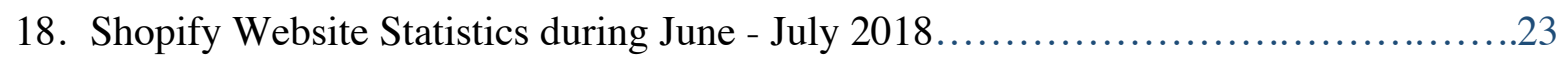




\section{Introduction of Virtual Fitting Room}

E-commerce has become of increasing significance in the competitive world of retail. As of 2017, e-commerce transactions are growing at a rate of more than six times faster than brick-andmortar stores (Wood, 2018). In the past five years, new online retailers have entered the market as strictly online companies in an attempt to establish themselves in the most dynamic section of the industry (Gallino and Moreno, 2018). Moreover, traditional retailers have been enhancing their ability to interact with customers by using multiple channels, putting customers at the center of their 'omnichannel approach' and offering new combinations of information and fulfillment (Rigby, 2011). The value of creating a virtual fitting room ("VFR") is to offer a shopping experience that mimics reality. According to the Merriam Webster dictionary, virtual reality is defined as "a concept that immerses real people inside a fictional digital, virtual pace" (Finn, 2017). The virtual fitting room technology allows an individual to digitally try on different apparel on a 3D model generated based on respective body parameters specified by the individual before a potential purchase is made (Liu, Wang Su, Luo C. Gao, 2013). The central question this project has considered is: Does the virtual fitting room lead to an increase in 1) social media engagement and 2) product sales? To test the premise of this research, six Egyptian fashion designers with a weak online presence were assigned to an e-commerce platform with VFR technology. To measure the impact of VFR, a benchmark for social media engagement, sales and returns was provided by each designer. 


\section{Current Virtual Fitting Room Solutions}

Many proprietary solutions have been developed such as Fits.me, Metail, Virtusize and Shoefitr

(Gallino and Moreno, 2018). Research has shown that VFR helps the online customer make decisions when buying apparel. The Virtual Fitting Room presents customers with a simulated version of themselves that takes into account their body shape, size and weight (Hodgson, 2016). Current findings in the online retail space by industry experts such as Metail (a British technology company in the online retail industry that aims to make clothing fit for all by digitising every garment) that virtual reality provides a unique and memorable experience, which ultimately drives sales (Sheffield, 2017). Metail, which has digitized 80,000 garments, has a greater focus on digital and consumer experience (Hodgson, 2017). The company's patented digitization technology - the MeModel - combines digital images with actual body measurements to allow users to create a photorealistic 3D model of themselves in just a few seconds (Venture, 2017). With an alleged 92-96 percent accuracy, the MeModel technology reduces returns for commercial stores by up to five percent and increases sales by 22 percent (Metail, 2018). Such claims are what inspired this research to truly explore the impact of the VFR. Current research hypothesizes that the VFR is used to increase engagement levels of entertainment for shoppers, resulting in higher sales. 


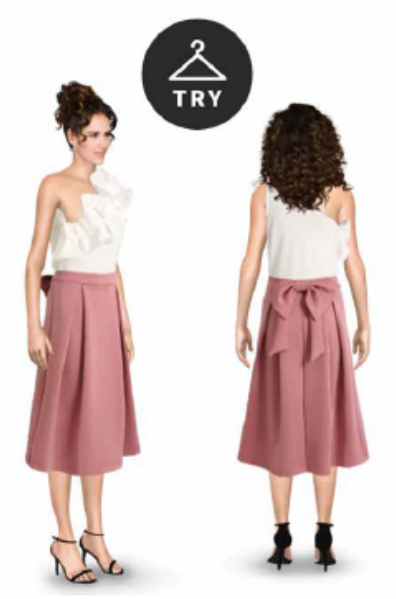

Figure 1: Metail Virtual Fitting Room

The process of VFR involves creating a personal avatar, as well as "accommodating a multitude of body variations, but also photographing clothes in such a way that can fit on all these different models" (Velardi, 2017). The objective behind the VFR is to increase the number of online purchases and empower customers to find body appropriate items, as well as to provide a generally enhanced customer experience (Hodgson, 2017). Virtual reality allows multisensory and intellectual engagement and creates emotional connection, enabling customers to have a meaningful experience with products (Finn, 2017). Using VFR allows retailers and brands to help drive the business by understanding more about customer preferences. These new forms of technology that are emerging are projected to create lasting effects in the e-commerce industry (Finn, 2017). According to research conducted by the Harvard Business Review (2016), emotional connections matter more than customer satisfaction since "build[ing] and investing in the touchpoints that drive these connections is a powerful way to increase customer value and maximize the return on investment decisions and minimize the risk" (Leemon and Zorfas, 2016). Surveys show that customers view VFR as a fun and novel way to explore options and determine which purchases they will ultimately make. 


\section{Background on the Egyptian Market}

VFR will be assigned to six Egyptian designers who currently do not have any online selling platforms aside from social media and/or a website or store front. We have chosen to focus our research on Egyptian designers because local Egyptian designers have been revolutionizing the fashion scene in the Middle East. According to findings obtained by surveying a sample of early adopters (i.e. young Egyptian females), respondents who fit the early adopter category indicated that they would rather purchase from local upcoming designers. The Egyptian designers selected in this intervention are known for their uniqueness in reviving the Egyptian heritage.

Local Egyptian designers and early adopters currently depend on cash as the primary form of payment. This presents unique challenges in the Egyptian market wherein implementing an e-commerce sales platform requires customized solutions such as an option to pay cash on delivery. Moreover, the majority of Egyptian designers sell their services or products predominantly via social media (Facebook and Instagram). However, they all use different channels, or as described in this intervention - "tools of engagement," - to sell their products. Thus, this intervention will examine the impact of VFR and what value it contributes to the level of overall customer engagement for Egyptian micro fashion brands.

\section{Current Findings on The Problem of 'Fit'}

A current problem in the market is that shoppers have trouble with sellers because there is a discrepancy between the pictures listed online and the clothing they ultimately receive. Studies by the University of South Carolina suggest that many online apparel orders may fit well on a standard mannequin, but do not properly fit the body of the specific shopper, which leads to an unsatisfactory shopping experience (Cohen, 2014). The primary drawbacks of shopping online are that customers return 40 percent of apparel to the designer because of inappropriate sizing 
(Dockterman, 2018). Thirty percent of returns due to the improper fit not only result in extra shipping fees and wasted time for shoppers, but also create disloyalty for those shoppers translating into a loss of the brand's goodwill (Saleh, 2017). Therefore, VFR services have been created to rectify this problem. The virtual fitting room often referred to as the virtual try-on can deliver product information that is similar to the information obtained from direct product examination (Forsythe and Kim, 2008). Although customers have embraced the online shopping model, the overall profit for online merchants suffers because of the high level of product returns due to poor fit.

\section{Literature Review}

The discrepancy in online and offline channels has always been present, and the ability to deliver product information effectively has been recognized as a key issue in e-commerce (Lal and Sarvay 1999). Why is this important? For the past decade, research has indicated that the "interactive nature of websites has been credited with increasing the desire to browse and purchase online" (Gehrke and Turban 1999; Harnett, 2000). There is a current gap in this field as stated in many pieces of literature expressing that "we have not found literature that experimentally examines the effect of image interactivity functions on approach responses towards an online retailer" (Fiore and Jin, p. 41, 2003). According to a study published by Oxford Economics (2018), small and medium sized businesses are beginning to adopt emerging technologies such as machine learning, artificial intelligence, augmented and virtual reality. Sixty-two percent of retailers surveyed stated that the digital transformation is critical to the company's survival (Petro, 2018). The research question addressed in this project is to assess whether or not implementing VFR increases the level of customer engagement, as measured through social media and website conversions. 


\section{Interactivity}

Research for the past decade has indicated that the "interactive nature of websites has been credited with increasing the desire to browse and purchase online (Gehrke and Turban 1999;

Harnett, 2000). Moreover, experts are suggesting that "enhancing the interactivity of a website is seen as a means of giving the site a competitive edge and in having a desire to browse and purchase online" (Fiore and Jin, 2003). Thus, we can assume that implementing VFR into an ecommerce website will produce an added value. It can be assumed as well that by adding VFR engagement will be increased.

\section{Contributions of Existing Research}

There are many studies discussing the advantages of adopting the virtual fitting room technology. For instance, one study suggests customers often have trouble with sellers because the clothing they received, and the pictures are discrepant (Huang, 2011). Another study claims that "although the virtual try-on technology has the potential to affect online shopping significantly, there is virtually no published research examining customer adoption of this technology" (Forsythe and Kim, 2008). It has been proven that "image interactivity functions of apparel retailers, such as Guess.com's 'mix or match or lanebryant.com's My Virtual Model ${ }^{\mathrm{TM}}$, may evoke an active process control, enjoyment, presence vividness, and involvement (Fiore and Jin, p. 41, 2003). Current research has been pursued in proving that VFR is used to increase interactivity, engagement, and levels of entertainment for shoppers. For instance, claims have been made that consumer purchase decisions are motivated by their senses when observing the product. Research has shown high touch merchandise varies by size, texture, color and it tends to create a perception of purchase risk on the internet (Yang \& Young, 2008). Furthermore, this high level of purchase risk may lead to consumers spending more time searching for product 
information and demanding a more interactive shopping experience than they would from other product categories (Yang \& Young, 2008). Yang \& Young have proven that virtual models assist in the reduction of consumer purchase risks while enhancing shopping experiences through interactivity. "Consumers react more actively to technology-based service encounters, enabling consumers to experience a product prior to its purchase on the internet" (Yang \& Young, 2008). The study further explains that customized site features are effective as consumer purchasing decision aids since they will positively affect consumer attitudes toward internet apparel shopping. The research has shown that virtual fitting rooms have benefitted both parties being the consumer and designer but have not indicated the factors behind this success. Therefore, this might suggest that it will lead to an increase in sales. The theory of greater engagement leading to increased sales will be explored in this research.

\section{VFR as a Social Sales Aid}

Existing literature currently shows that consumers increase their exploratory behavior, trust, positive emotions, purchase intention, and satisfaction with the website in the presence of a new social sales aid (Beck and Crie, 2016). Beck and Crie explain that the VFR has a positive effect on consumers' intention to purchase, power of retention of the website, and trust in the product; since it allows them to try on and visualize the product (2016). The study by Beck and Crie determined the impact of VFR by performing a qualitative study of university students accessing the website with VFR versus an e-catalogue. Moreover, recent work has studied questions related to product uncertainty and its implications for e-commerce. For instance, Dimoka et al. (2012) state that product uncertainty is a major obstacle for e-commerce that can be reduced by technology solutions. They theorized that product uncertainty is defined as "the buyer's difficulty in assessing the product's characteristics and predicting how the product will perform 
in the future". They further explain that product uncertainty has two facets: description uncertainty (difficulty obtaining reliable information about the product's true quality) and performance uncertainty (difficulty predicting how the product will perform in the future) (Dimoka et $\mathrm{Al}$ 2012). The work in this project further explores mitigating the issue in ecommerce through the use of the VFR in monitoring the engagement rate of 3D technology. Baker, Wagner, Wang, and Wakefield (2007) investigate how social cues inherent in avatars can influence the customers affect and shopping value. They draw conclusions that avatars can increase persuasiveness as an online sales channel. Their findings suggested that social cueinduced arousal leads to increased pleasure only for consumers who are involved with the product category. Moreover, they explain that the influence of arousal is stronger for women and is more important for younger generations and models online shopping behaviour (Baker, Wagner, Wang, and Wakefield, 2007).

Another study by Papadopoulu (2006) dealt with applying virtual reality for trust building in e-commerce environments. The study focused on factors that influence trust to entice the customer when interacting in an online store (i.e. the social context and behavioral impacts of virtual reality e-commerce applications). She explains that shopping is a social process in real life and thus should be mirrored online through the virtual fitting room. By 'stimulating a realworld experience' it enables trust, one of the most prominent and successful aspects of shopping, a social experience. She continues to explain the importance of trust as a critical success factor for e-commerce and identifies it as the "greatest barrier inhibiting online commercial transactions" (2006). In a qualitative study, Papadopoulu highlights the evaluation of the virtual ecommerce environment: 
"It's definitely more impressive to have a 3D view of a product and to be able to observe

it from different perspectives by rotating it give more information about the product than a 2D in a current ecommerce website."

A prototype virtual e-commerce environment was designed in her study that posits that virtual reality technologies are effective in offering a rich and sophisticated customer experience compared to conventional stores. In this project the value of VFR technology is assessed, overseeing the implementation of a series of interventions. Providing that the technology is accessible to customers, we hypothesize that providing this opportunity will reduce the friction arising from selling clothes online. The idea of VFR is to steer away from traditional online e-commerce and move towards a more personal customer engagement shopping experience.

\section{Methodology}

This research aims to explore the impact of sales from implementing a VFR experience. Young Egyptian females were anonymously asked through a series of questions what designers they would rather see online. In addition, questions that were asked to the designers can be found in Appendix B. In order to prove this theory of VFR implementation, six Egyptian designers were assigned to an e-commerce platform that we created. Each of the six designers placed four garments on the e-commerce website, which were then fully digitized for VFR, resulting in a total of twenty-four garments that could be worn in a virtual fitting room. These designers added different engagement tools to their online offerings in order to increase the level of engagement using their original historical state as a benchmark. The engagement tools were used in the VFR website and social networks were monitored over a period of one month. Three engagement tools or configurations were present: social media only, social media and store front and the final 
state: social media, website, store-front and implementing the virtual fitting room on an ecommerce website.

\begin{tabular}{|c|c|c|c|c|}
\hline Designer & Social Media & $\begin{array}{c}\text { Social Media }+ \\
\text { Website }\end{array}$ & $\begin{array}{c}\text { Social Media + } \\
\text { Store-front }\end{array}$ & $\begin{array}{c}\text { Optimal State SM + } \\
\text { Website + Store- } \\
\text { front + VFR }\end{array}$ \\
\hline 1 & $\mathrm{X}$ & $\mathrm{X}$ & & $\mathrm{X}$ \\
\hline 2 & $\mathrm{X}$ & $\mathrm{X}$ & $\mathrm{X}$ \\
\hline 3 & $\mathrm{X}$ & $\mathrm{X}$ & $\mathrm{X}$ & $\mathrm{X}$ \\
\hline 4 & $\mathrm{X}$ & $\mathrm{X}$ & $\mathrm{X}$ & $\mathrm{X}$ \\
\hline 5 & $\mathrm{X}$ & & $\mathrm{X}$ & $\mathrm{X}$ \\
\hline 6 & & & 3 & $\mathrm{X}$ \\
\hline TOTAL & 6 & 3 & 3 & 6 \\
\hline
\end{tabular}

Figure 2: Data Collected showcasing Engagement Tools used by Designers

\begin{tabular}{|c|c|c|c|}
\hline $\begin{array}{c}\text { Type of Online } \\
\text { Presence }\end{array}$ & Designer Name & Followers & $\begin{array}{c}\text { Number of Products } \\
\text { taken }\end{array}$ \\
\hline Only Social Media & Farah Wagdy & 15,000 & 4 \\
\hline $\begin{array}{c}\text { Only Social Media + } \\
\text { Web }\end{array}$ & Canvas Label & 1,500 & 4 \\
\hline & Fadomo Designs & 1,400 & 4 \\
\hline $\begin{array}{c}\text { Social Media + Web + } \\
\text { Store }\end{array}$ & RAMLA & 1,300 & 4 \\
\hline & Camicie & 14,000 & 4 \\
\hline
\end{tabular}

Figure 3: Type of Online Presence \& Engagement Tools used by Designers 


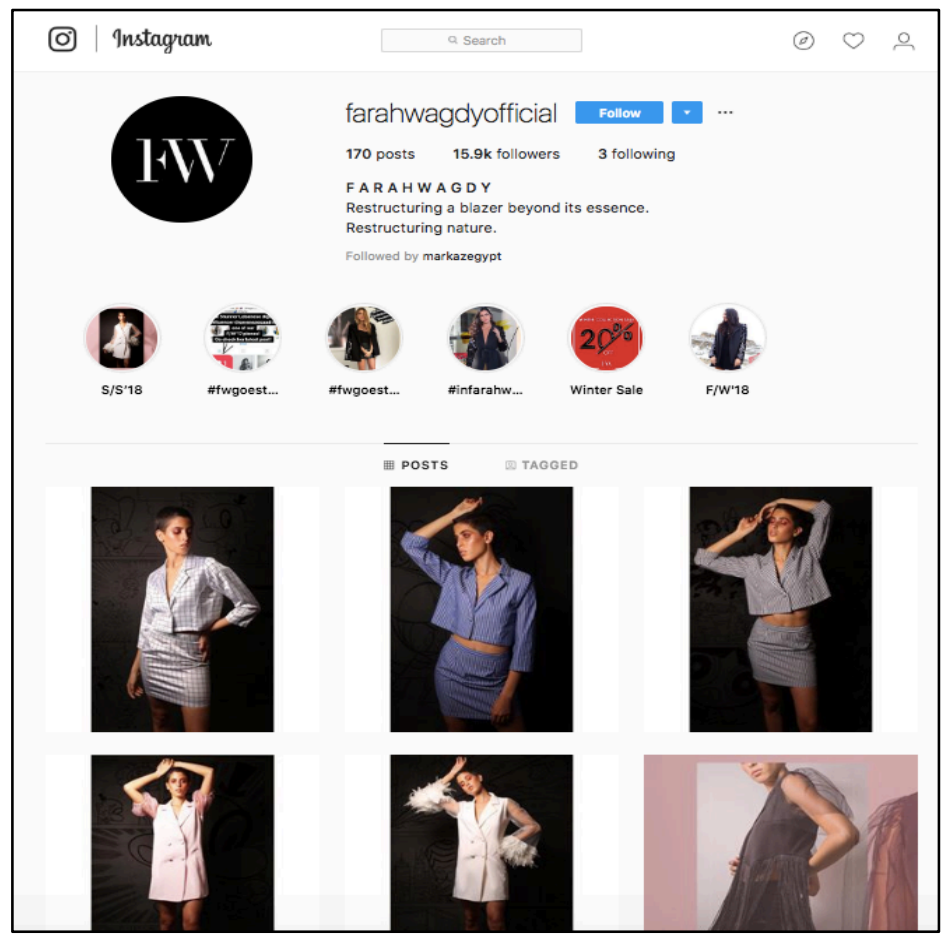

Figure 4: Instagram page for Designer (Farah Wagdy) with presence only on social media.

This research was conducted in collaboration with Virtual Outfits LLC ("Virtual Outfits"), a virtual fitting room platform based in Los Angeles California. Virtual Outfits has a patent for three-dimensional model generation based on two dimensional images (Optics \& Imaging Patent News,2018). This experiment added VFR technology in an effort to increase customer engagement and increase sales and decrease returns, as measured through social media and website conversion rates. The images below convey the capabilities of the technology, allowing users to personalize skin color, body-shape, body-size and measurements (Figure 5). 


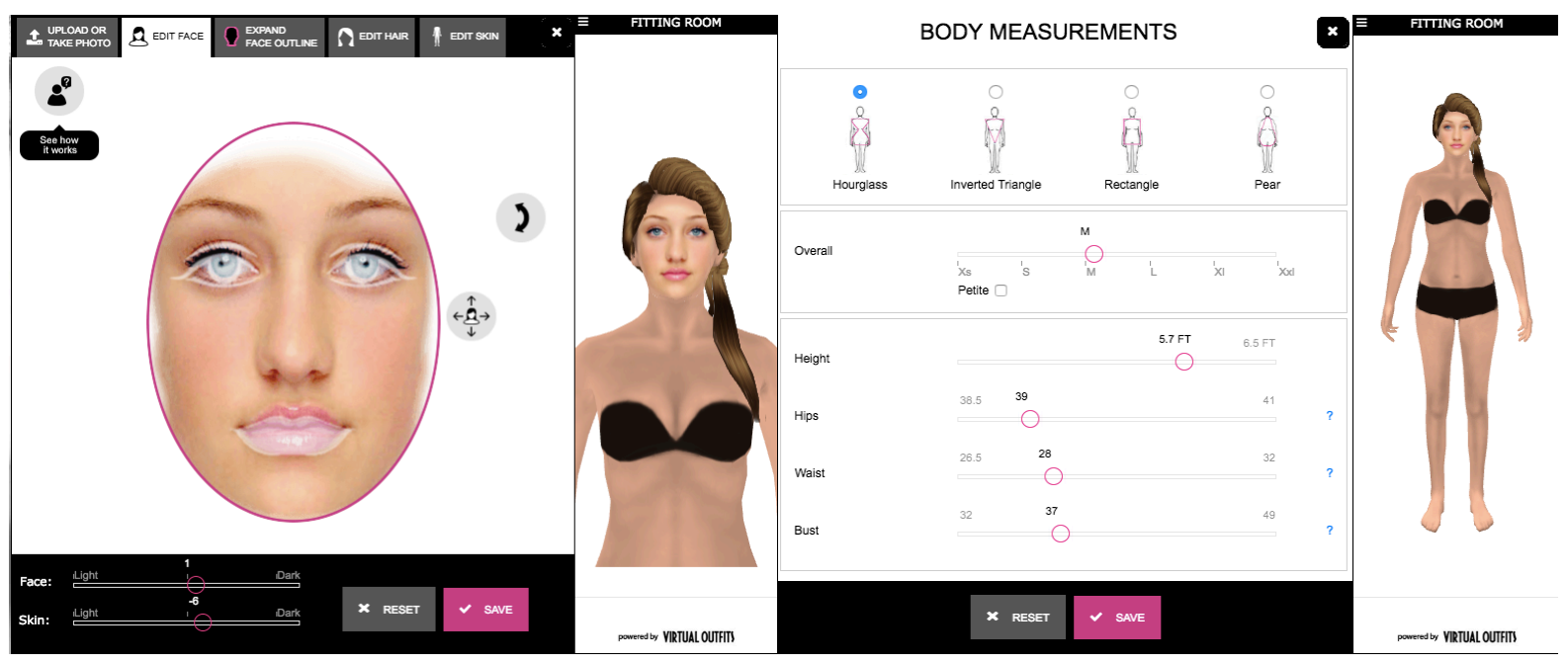

Figure 5: Customizing Avatar Body Size \& Dimensions using Virtual Outfits LLC

\begin{tabular}{|l|l|}
\hline Tool 1 & Social Media \\
\hline Tool 2 & Social Media + E-Commerce Website \\
\hline Tool 3 & Social Media + E-Commerce Website + Virtual Fitting Room \\
\hline
\end{tabular}

Figure 6: Three Engagement Tools used in this project.

Features of the technology include seeing the product in 3D as seen in Figure 7. Virtual outfits allow users to engage in a new social shopping experience through the ability to mix and match different products in the closet and try them on together. 


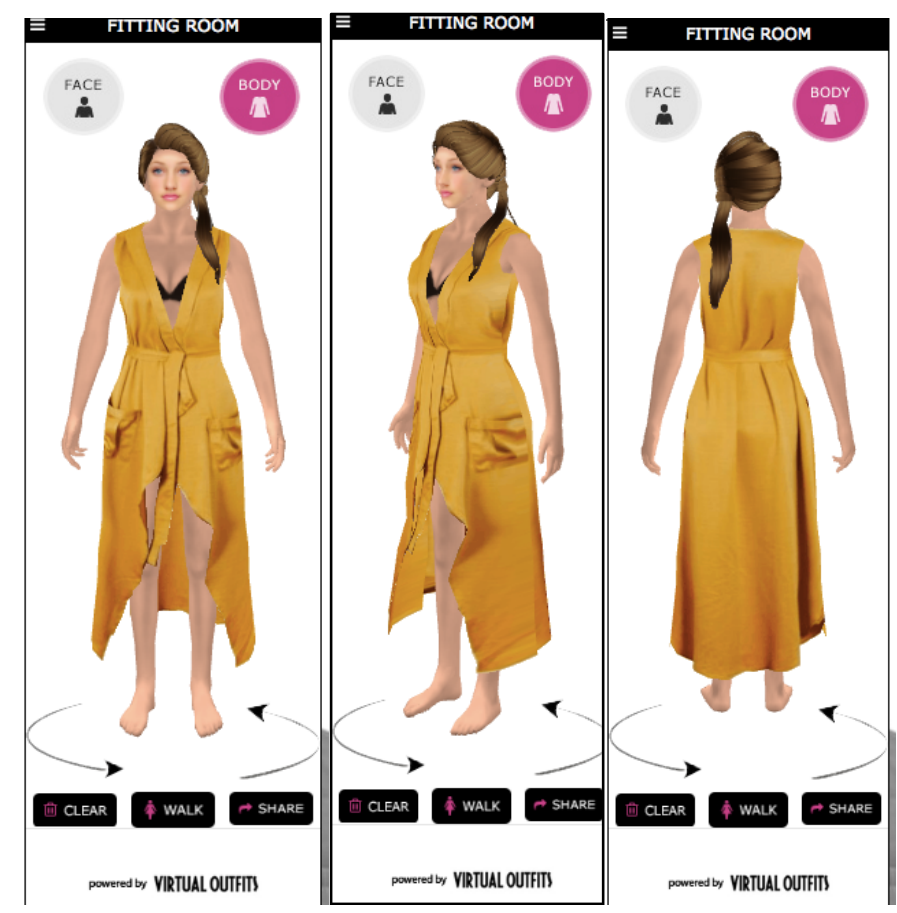

Figure 7: 3D Avatar wearing Garment made by Designer: Camicie

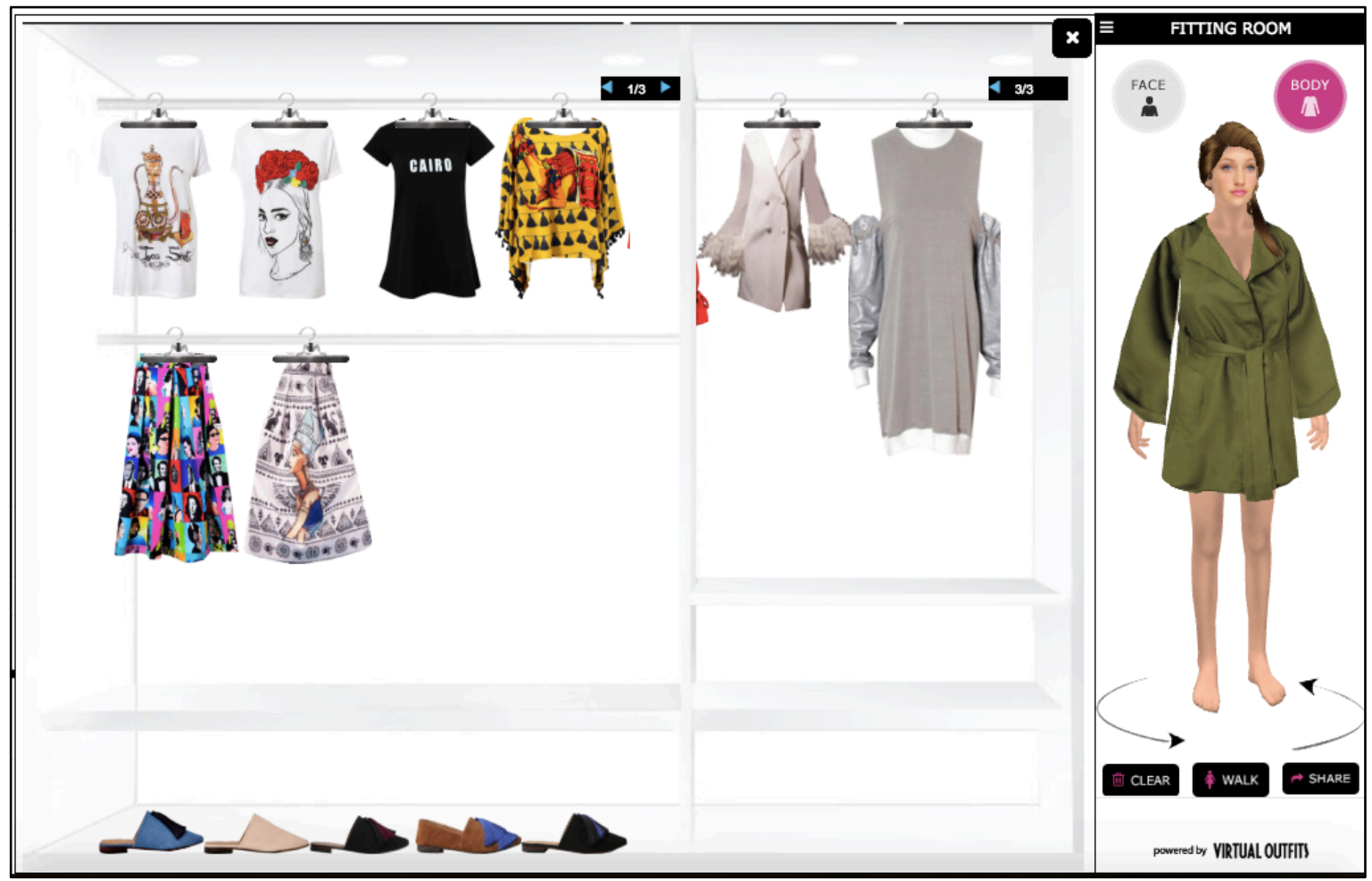

Figure 8: Virtual Outfits Closet displaying Egyptian designer's products. 
Secondly conducting an A/B test through social media where different engagement configurations were monitored and collected over a period of a month. Baseline values of overall views and impressions were first collected as benchmarks. Three engagement tools were present: social media, social media and store front and the final state of social media, website, store front and implementing the virtual fitting room. Additionally, overall engagement on social media and the website reports from Virtual Outfits was analyzed both with and without an avatar.

\section{Results}

The table below illustrates the results of the experiment. The experiment was conducted over a period of one month from June 1- July 31, 2018. Each of the six designers made sales through the website. However, the number of sales did not exceed the baseline sales (See Figure 9 below). Since returns are accepted for up to 30 days, returns were not encountered for the duration of the experiment. The three designers that do sell in a physical storefront in addition to online demonstrated greater success. According to the designers, this could be because they have more exposure in the market. 


\begin{tabular}{|c|c|c|c|c|c|c|}
\hline & & & \multicolumn{2}{|c|}{ SALES \# Of Pieces Sold } & \multicolumn{2}{|c|}{ RETURNS } \\
\hline $\begin{array}{l}\text { Egyptian } \\
\text { Designer }\end{array}$ & $\begin{array}{c}\text { \# of Clothing } \\
\text { Garments }\end{array}$ & $\begin{array}{l}\text { Designers } \\
\text { that have a } \\
\text { physical } \\
\text { storefront }\end{array}$ & $\begin{array}{c}\text { Base Sales } \\
\text { History of } \\
\text { Pieces Sold }\end{array}$ & $\begin{array}{c}\text { Post } \\
\text { Experiment }\end{array}$ & $\begin{array}{c}\text { Base } \\
\text { Return } \\
\text { History }\end{array}$ & Post \\
\hline 1 (F.D.) & 4 & - & 10 & 1 & 0 & $\mathbf{0}$ \\
\hline 2(N.A.) & 4 & YES & 50 & 4 & 5 & $\mathbf{0}$ \\
\hline 3(C.L) & 4 & - & 8 & 1 & 0 & $\mathbf{0}$ \\
\hline $4(\mathrm{R})$ & 4 & YES & 6 & 3 & 1 & $\mathbf{0}$ \\
\hline 5(F.W.) & 4 & - & 13 & 2 & 0 & $\mathbf{0}$ \\
\hline $6(C)$ & 4 & YES & 80 & 1 & 3 & $\overline{\mathbf{0}}$ \\
\hline Total & 24 & 3 & 167 & 12 & 9 & $\mathbf{0}$ \\
\hline
\end{tabular}

Figure 9: Designers Average Sales \& Return Data

The null hypothesis of this experiment is that the virtual fitting room does not increase sales and does not increase returns. The key independent variables in this project were the three states of this experiment: social media alone; social media with ecommerce; and finally, social media, ecommerce and the virtual fitting room.

We are analyzing the changes in three different states, illustrated in the engagement tools. Social engagement was measured primarily through Instagram. Pictures of each designer's products were placed on the social media channel created for this experiment, and an $\mathrm{A} / \mathrm{B}$ test was carried out. The likes, reach, and views were analyzed during the duration of the experiment. The values in the last column (percentage of impact) fluctuate between 32 per cent to 114 per cent from only social media to the final state of social media, e-commerce and storefront. The baseline data is illustrated below conveying the three engagement tools before the virtual fitting room was implemented. In the last column on the right, the difference of reach is illustrated to see the impact VFR has on the products. 


\begin{tabular}{|c|c|c|c|c|c|}
\hline $\begin{array}{c}\text { Before VFR } \\
\text { Implementation }\end{array}$ & Designer Name & Likes & Reach & Views & $\begin{array}{l}\text { Difference of } \\
\text { REACH is } \\
\text { (\%Impact) }\end{array}$ \\
\hline \multirow[t]{2}{*}{ Only Social Media } & Farah Wagdy & $\begin{array}{r}88 \\
\underline{60} \\
148\end{array}$ & $\begin{array}{l}157 \\
404 \\
\mathbf{5 6 1}\end{array}$ & $\begin{array}{l}200 \\
\underline{252} \\
452\end{array}$ & $\begin{array}{l}761 \text { vs } 2338 \\
\text { (after) }=\mathbf{3 2 \%}\end{array}$ \\
\hline & Canvas Label & $\begin{array}{r}60 \\
52 \\
112 \\
\end{array}$ & $\begin{array}{l}280 \\
250 \\
\mathbf{5 0 0} \\
\end{array}$ & $\begin{array}{l}130 \\
160 \\
190\end{array}$ & \\
\hline \multirow[t]{2}{*}{$\begin{array}{c}\text { Only Social Media + } \\
\text { Website }\end{array}$} & Fadomo Designs & $\begin{array}{l}43 \\
25 \\
68\end{array}$ & $\begin{array}{c}662 \\
\underline{395} \\
\mathbf{1 , 0 5 7}\end{array}$ & $\begin{array}{l}412 \\
270 \\
683\end{array}$ & $\begin{array}{c}2006 \text { vs } 3594 \\
=\mathbf{5 5 \%}\end{array}$ \\
\hline & RAMLA & $\begin{array}{l}56 \\
37 \\
93 \\
\end{array}$ & $\begin{array}{l}484 \\
465 \\
949 \\
\end{array}$ & $\begin{array}{l}373 \\
338 \\
\mathbf{7 1 1} \\
\end{array}$ & \\
\hline \multirow[t]{2}{*}{$\begin{array}{c}\text { Social Media + } \\
\text { Website+ } \\
\text { Storefront } \\
\end{array}$} & Nada Akram & $\begin{array}{r}52 \\
\underline{50} \\
\mathbf{1 0 2}\end{array}$ & $\begin{array}{r}641 \\
446 \\
\mathbf{1 0 8 7}\end{array}$ & $\begin{array}{l}453 \\
\underline{333} \\
\mathbf{7 8 6}\end{array}$ & $\begin{array}{c}4012 \text { vs } 35100 \\
\mathbf{1 1 4 \%}\end{array}$ \\
\hline & Camicie & $\begin{array}{l}45 \\
52 \\
97\end{array}$ & $\begin{array}{l}1,900 \\
\underline{1,025} \\
\mathbf{2 , 9 2 5}\end{array}$ & $\begin{array}{l}1,720 \\
\frac{990}{2,710}\end{array}$ & \\
\hline
\end{tabular}

Figure 10: Before VFR Implementation Designers Instagram Data

* Views is the total number of times that your content is displayed in the news feed

* Reach is the total number of people who viewed your post.

*Likes are the number of people who liked your post 


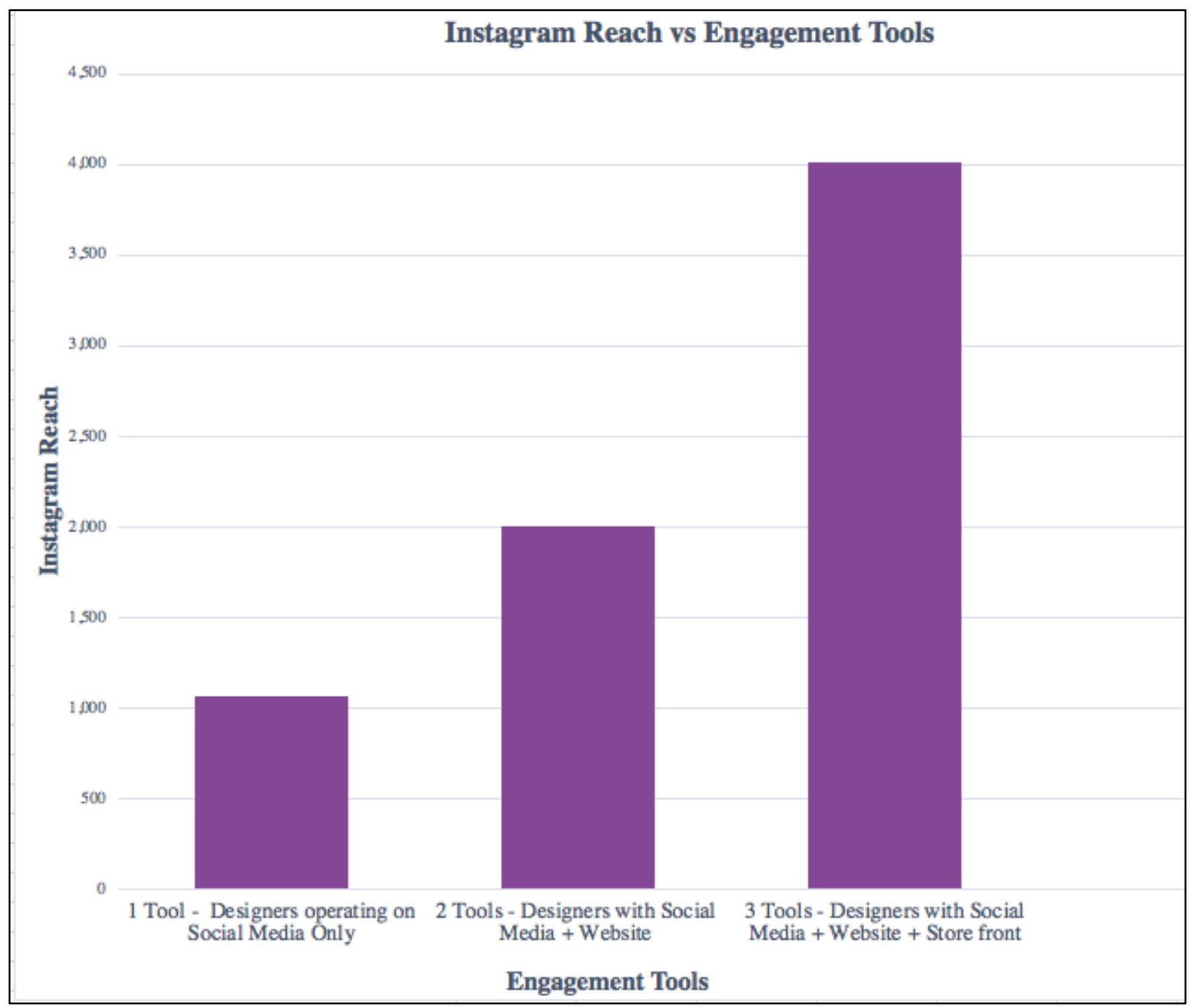

Figure 11: Before VFR Implementation Designers Instagram Data 
For this bar graph, it is apparent in our findings that the more engagement tools used the higher the Instagram reach. After talking to many designers during the intervention, they realized that the more exposure they have online (i.e. more engagement tools) the greater the response. While it is expected that the availability of a virtual fitting room will increase online sales and engagement, our analysis shows that the benefits of a virtual fitting room relate to increased engagement level.

\begin{tabular}{|c|c|c|c|c|}
\hline $\begin{array}{l}\text { After the VFR has been } \\
\text { implemented into each of } \\
\text { these channels - } \\
\text { Optimal State }\end{array}$ & Designer Name & Likes & Reach & Views \\
\hline \multirow[t]{2}{*}{ Only Social Media } & Farah Wagdy & $\begin{array}{l}100 \\
\underline{120} \\
220\end{array}$ & $\begin{array}{l}504 \\
400 \\
904\end{array}$ & $\begin{array}{l}280 \\
180 \\
460 \\
\end{array}$ \\
\hline & Canvas Label & $\begin{array}{r}68 \\
\underline{38} \\
106\end{array}$ & $\begin{array}{l}429 \\
347 \\
776\end{array}$ & $\begin{array}{l}303 \\
\underline{220} \\
\mathbf{5 2 3}\end{array}$ \\
\hline Only Social Media + Website & Fadomo Designs & $\begin{array}{l}28 \\
67 \\
95\end{array}$ & $\begin{array}{r}672 \\
890 \\
1562\end{array}$ & $\begin{array}{r}882 \\
640 \\
\mathbf{1 5 2 2} \\
\end{array}$ \\
\hline & RAMLA & $\begin{array}{l}56 \\
\underline{37} \\
93\end{array}$ & $\begin{array}{c}465 \\
1,567 \\
\mathbf{2 0 3 2}\end{array}$ & $\begin{array}{r}338 \\
850 \\
\mathbf{1 1 8 8}\end{array}$ \\
\hline $\begin{array}{c}\text { Social Media + Website + } \\
\text { Store-front }\end{array}$ & Nada Akram & $\begin{array}{r}52 \\
\underline{62} \\
\mathbf{1 1 4}\end{array}$ & $\begin{array}{l}1,100 \\
\underline{3,800} \\
4900\end{array}$ & $\begin{array}{c}860 \\
1,100 \\
\mathbf{1 9 6 0}\end{array}$ \\
\hline & Camicie & $\begin{array}{r}72 \\
\frac{55}{127} \\
\end{array}$ & $\begin{array}{l}17,200 \\
13,000 \\
\mathbf{3 0 , 2 0 0} \\
\end{array}$ & $\begin{array}{l}13,958 \\
10,320 \\
\mathbf{2 4 , 2 7 8} \\
\end{array}$ \\
\hline
\end{tabular}

* Impressions is the total number of times that your content is displayed in the news feed

* Reach is the total number of people who viewed your post

*Likes are the number of people who liked your post

Figure 12: After VFR Implementation Designers Instagram Data 
The second chart below illustrates the results of the $\mathrm{A} / \mathrm{B}$ test of the the level of engagement after the virtual fitting room was implemented on social media. It is apparent through the chart that the Instagram reach was higher after implementation of the virtual fitting room. The values in the reach column were the highest and thus were used in comparing the two states with the virtual fitting room and without. It is also apparent that the more online channels used, the higher the reach was after implementation of the virtual fitting room. 


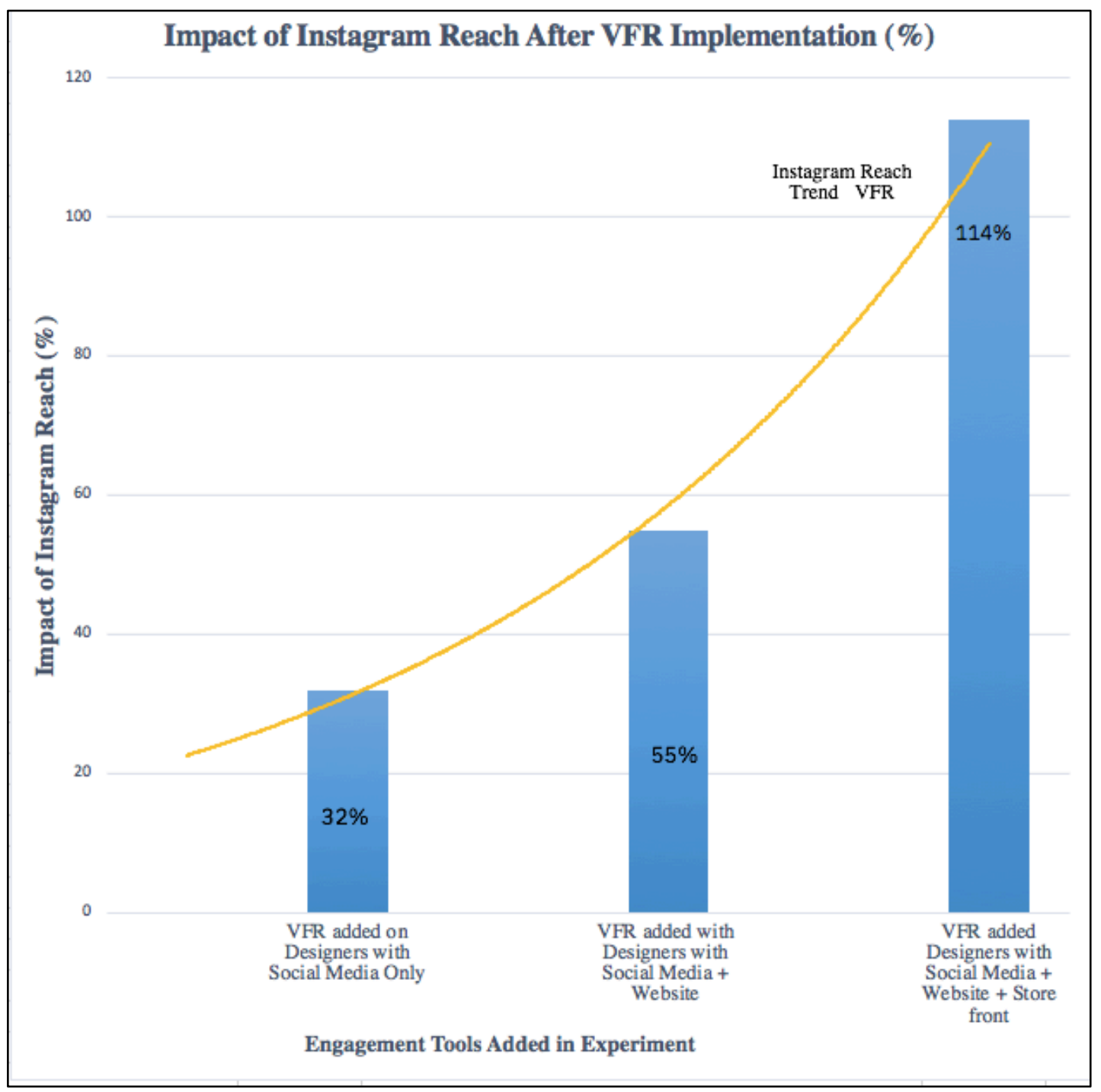

Figure 13 Impact of Instagram Reach After VFR implementation

As seen in the graph above, the yellow trend line displays the curve in which increased online tool usage leads to the higher Instagram reach. Studies show that these technologies have allowed consumers to save time and enjoy the shopping experience, emerging as a promising line of inquiry for new research in online retailing and e-commerce (Dey and Sandor, 2014). 
우

Instagram

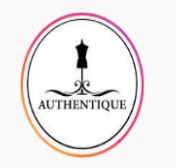

shopauthentique.co following
73 posts 1,281 followers 895 following

Authentique

Egyptian Designers, Torontonian Spirit.

Shop through our $3 \mathrm{D}$ virtual fitting room

$\forall$ authentically genunes

OT Torontolairo

goo.gl/quLr61

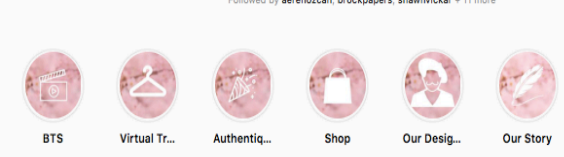

III Posts
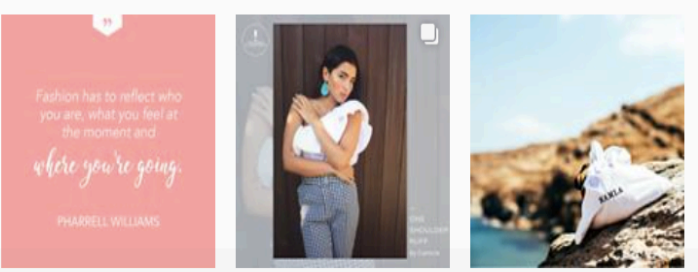

Figure 14: Instagram page Created during duration of experiment

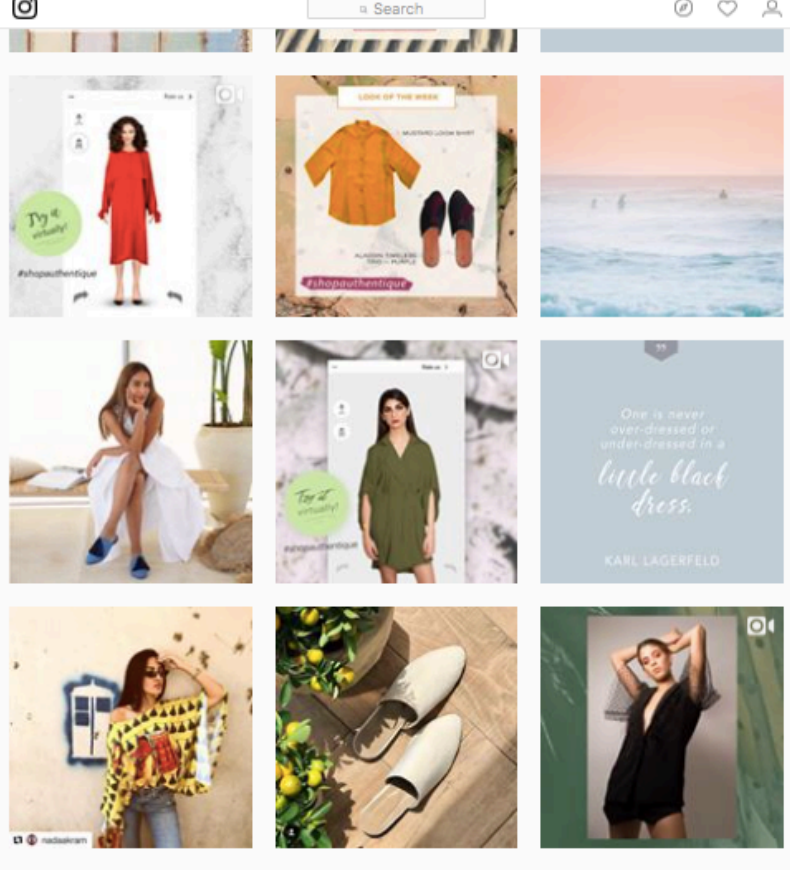

\begin{tabular}{|c|c|c|c|c|c|c|c|c|}
\hline $\begin{array}{c}\text { Used } \\
\text { Avatar }\end{array}$ & $\begin{array}{c}\text { Total } \\
\text { Users }\end{array}$ & $\begin{array}{c}\text { Public } \\
\text { User }\end{array}$ & Tryon & Walk & $\begin{array}{c}\text { Upload } \\
\text { Face }\end{array}$ & $\begin{array}{c}\text { Changed } \\
\text { Body }\end{array}$ & $\begin{array}{c}\text { Add to } \\
\text { Cart }\end{array}$ & $\begin{array}{c}\text { Return } \\
\text { Users }\end{array}$ \\
\hline Yes & 95 & 94 & 160 & 24 & 1 & 31 & 0 & 23 \\
\hline No & 88 & 88 & 1 & 0 & 0 & 0 & 0 & 21 \\
\hline $\begin{array}{c}\text { Percentage } \\
(\%)\end{array}$ & 95 & $98.9 \%$ & $168.42 \%$ & $25.26 \%$ & $1.05 \%$ & $32.63 \%$ & $0 \%$ & $25 \%$ \\
\hline & 88 & $100 \%$ & 1.14 & 0 & 0 & $0 \%$ & $0 \%$ & $23.88 \%$ \\
\hline & & & & & & & & \\
\hline
\end{tabular}

Figure 15: Virtual Outfits LLC, Monthly Avatar Try-on Report

According to reports by Virtual Outfits, 95 percent of users who went onto the website used the virtual fitting room. However, only 25 percent of users returned to use it again. Reports indicate that they used the try-on, walk, and changed body the most. It is also apparent that none of the users added a product to cart. 


\begin{tabular}{|c|c|c|c|}
\hline Performance of Users & Total Segment & After Try-On & $\begin{array}{c}\text { Non-users Total } \\
\text { Segment }\end{array}$ \\
\hline Time/Session & $5.04 \mathrm{~min}$ & $3.84 \mathrm{~min}$ & $1.88 \mathrm{~min}$ \\
\hline Try- On Adoption Rate & - & $53.78 \%$ & - \\
\hline Average \# of Look/User & - & 3.14 & - \\
\hline Total Users for Segment & 95 & 51 & 88 \\
\hline
\end{tabular}

* Total segments the users that came to the site, changed avatar or look at the closet, including try-on and outfit making.

* None Users segment mean cellphone and none 3D systems

* After Try-On means the user came to your site and clicked on try-on

\section{Figure 16: Virtual Outfits LLC, Performance of Users Report}

According to claims provided by Virtual Outfits, it is evident that the greater numbers of users prefer to use an avatar. The monthly report states that 160 users used the virtual try-on tool during the one-month duration. It is interesting to highlight that 25 percent of these users were return users, who even if a purchase was not made, came back to utilize the tool again. Moreover, users spent approximately over five minutes during the session of try-on. After the users finished using the tool they were on the website for 3.84 minutes on average. It is stated that almost 54 per cent of users that found the virtual fitting room used it. We can conclude from these results that the users are engaged with a virtual try-on more than a website. 


\section{Discussion}

The findings of experiments showed the positive effects of adding a virtual fitting room. The level of engagement in this project suggests that there is a positive correlation between engagement and virtual fitting rooms. VFR increases desire, motivating consumers to have interest in and give more attention to the product. In agreement with previous research by Aromne al. (2011), Smith and Swinyard (1988) and Kaltcheva et al. (2011) we can say that VFR increases perceptual specific curiosity increasing desire and motivation in regard to the product (Brie and Crie, 2016). Research from Baker, Wagner, Wang, and Wakefield (2007) also affirms this idea that VFR can increase the persuasiveness of online channels. Moreover, VFR provides social cues of engagement.

\begin{tabular}{|c|c|c|}
\hline HYPOTHESIS & DESCRIPTION & Supported by EXPERIMENT \\
\hline 1 & $\begin{array}{c}\text { Virtual Fitting Room } \\
\text { increases the probability of purchase }\end{array}$ & Supported \\
\hline 2 & $\begin{array}{c}\text { Virtual Fitting Room } \\
\text { Increases the engagement of on social } \\
\text { media }\end{array}$ & TBD \\
\hline 3 & $\begin{array}{c}\text { Virtual Fitting Room increases the } \\
\text { amount of sales and decreases returns }\end{array}$ & \\
\hline
\end{tabular}

Figure 17: Hypothesis Incurred in the Experiment

VFR technology attempts to reduce the stigma that most online e-commerce businesses have: reducing abandoned shopping cart rates and the cost of returns. According to our data website statistics suggest that there was still a high number of abandoned shopping carts, approximately 38 in total (Refer to Figure 18 below). During the duration of the experiment the number of sessions were adequate, 880 unique visitors were highs for a new website. According to studies conducted by Shopify, online website visitors should reach 1,000 upon the first month of launch 
in the fashion e-commerce space. However, Shopify explains that it's not just about website visitors, it's about the conversion rate, advertising and of course sales (Wahbe, 2018). If in fact more sales were present, then we could draw conclusions that VFR decreases the frequency of abandoned shopping carts.

\begin{tabular}{|c|c|}
\hline Website Traffic & \# of Users \\
\hline Website Visitors & 880 \\
\hline Sessions & 1,385 \\
\hline Added to Cart & 38 \\
\hline
\end{tabular}

Figure 18: Shopify Website Statistics during June-July 2018

Papadopoulu (2007) also confirms that virtual reality's presence is an integral part of ecommerce, for it can address the critical need of harmonizing the technical and social aspects of online shopping. It is concluded in her study that adding a virtual reality e-commerce environment is superior and preferred over conventional websites for shopping (Papadopoulu, 2007). Interestingly, she explains the perceived satisfaction resulting from the interaction stages in the 3D representation of a product as allowing for a rich product experience and a complete view and examination of the product which is missing from conventional online stores" (Papadopoulu, 2007).

On the other hand, Baker, Wagner, Wang, and Wakefield (2007) investigate how social cues inherent in avatars can influence the customers' affect and shopping value. They draw conclusions that avatars can increase persuasiveness as an online sales channel. Their findings suggest that social cue-induced arousal leads to increased pleasure only for consumers who are 
involved with the product category. The influence of arousal is stronger for women, and is more important for younger generations (Baker, Wagner, Wang, and Wakefield, 2007).

Based on my research, it can be concluded that the utilization of more engagement tools, leads to a higher social reach and thus results in higher effectiveness of the virtual fitting room.

Ultimately, according to our data the VFR increases the probability of purchase, but we cannot confirm that it decreases the amount of returns.

\section{Limitations and need for further research}

Before concluding, we need to be vigilant of the limitations in this research. The interpretation of the results is limited in that this project was not able to completely affirm the hypothesis of VFR; increasing sales of the designers' products within the timeframe potential. In addition, it is important to note that the duration of the experiment was limited and focused on a niche audience. Even though the data showed users spending over 5 minutes using VFR, it is also important to mention that the research would have proved to show more data if it was carried out during a longer period and focused on designers that have a storefront. This work provides a theoretical rationale for the means of VFR influence on consumer experiences. The results show that the VFR can facilitate the social engagement of consumers. The exploratory nature of this research suggests some potential topics need to be further investigated. Firstly, it would be interesting to monitor the data over a longer time frame to discover if the VFR speeds up the online shopping cycle of garments. Secondly, the current findings of this research should encourage further consideration of social engagement, monitoring a closer connection between the products tried and the user's behaviour towards the products. Thirdly, the research should be using a larger sample of subjects. 


\section{Conclusion}

The findings of experiments showed the positive effects of adding a virtual fitting room. The advances in virtual reality and 3D graphics have greatly enticed the e-commerce retail industry $(\mathrm{Li}, 2011)$. Unlike other research to date, this project measured the level of engagement of the virtual fitting room using social media. The level of engagement in this project suggested that there is a positive correlation between engagement and the virtual fitting room. VFR increases the desire that motivates consumers to have an interest in and give attention to a product. Thus, it can be concluded that increased engagement leads to a higher social reach. Our findings also affirm that of Beck and Crie's, which states that the presence of social aids increases engagement for customers. Nevertheless, it is important to note, that this study did not quantitatively ascertain whether adding a virtual fitting room increases sales and decreases returns for designers, due to the limited timeframe of the experiment. Furthermore, future research should attempt to overcome the limitations of short-time frames by looking at a twelvemonth window. 


\title{
Appendices
}

\section{Appendix A:}

\section{Hypothesis}

\section{Proposal Experiment Setup}

\author{
Does adding a virtual fitting room sell more \& decrease customers returns?
}

\section{Assumption:}

The innovative virtual styling solution that will provide shoppers with a personalized and social shopping experience resulting in higher sales.

\section{Designing the Experiment: A \& B Test}

Do shoppers click more if there is a virtual fitting room available?

This experiment will be rolled out using 6 Local Egyptian Designers on Instagram. Each designer will advertise 4 of their top selling products. 2 products will carry out the regular 'shop the outfit online' (Hook A). And the other 2 of the products will be advertised with offering a virtual fitting room solution (Hook B). This experiment will test the effectiveness of the virtual fitting room solution in providing accurate sizing information to decrease returns for customers resulting an increase revenue for shoppers. This test will be carried over a month. Two posts will be scheduled a week per designer.

Find your best fit \& share your looks

Try on the latest collection using your own personalized avatar.

\begin{tabular}{|c|c|c|}
\hline Problem/ Solution Fit & Test A - Current State & Test B - Future State \\
\hline Channel & Instagram & Instagram \\
\hline $\begin{array}{l}\text { PCM } \\
\text { (Problem Centric Message) }\end{array}$ & $\begin{array}{l}\text { Just in! Shop this season's new } \\
\text { collection. }\end{array}$ & $\begin{array}{l}\text { Just in! Try on this season's new } \\
\text { collection with our virtual fitting } \\
\text { room! Available now! }\end{array}$ \\
\hline Call to Action & Click here to Shop now! & Click Here to TRY now! \\
\hline Sample Size & 1,000 & 1,000 \\
\hline $\begin{array}{l}\text { Success Metric } \\
\text { (increase in Conversion) }\end{array}$ & $\begin{array}{l}\text { (AARRR) Pirate Metrics } \\
\text { - } \quad \text { Acquisition - Viewing the ad } \\
\text { - } \quad \text { Activation - they click on ad } \\
\text { - Revenue - Checkout \& Pay } \\
\quad \text { friend - shared outfit with a } \\
\text { - Returns - which of these sales } \\
\quad \text { were sent back. }\end{array}$ & $\begin{array}{l}\text { (AARRR) Pirate Metrics } \\
\text { - Acquisition - Viewing the ad } \\
\text { - Activation - they click on ad } \\
\text { - Revenue - they try on fitting } \\
\text { room \& Pay } \\
\text { - Referral - shared outfit with a } \\
\text { friend } \\
\text { - Returns - which of these sales } \\
\text { were sent back }\end{array}$ \\
\hline
\end{tabular}




\section{APPENDIX B:}

\section{Confidential Summary of 6 Egyptian Designers Findings}

\begin{tabular}{|c|c|c|c|c|c|}
\hline $\begin{array}{c}\text { Channels of } \\
\text { Sale }\end{array}$ & $\begin{array}{c}\text { Designer } \\
\text { Name }\end{array}$ & \# of Returns & Reasons of Return & $\begin{array}{c}\text { Customer } \\
\text { Referrals }\end{array}$ & Findings \\
\hline $\begin{array}{c}\text { Only Social } \\
\text { Media }\end{array}$ & $\mathrm{X}$ & $1 \%$ & $\begin{array}{c}\text { 1 Felt } \\
\text { Uncomfortable } \\
\text { Did not like the } \\
\text { product }\end{array}$ & $\begin{array}{c}\text { Word of } \\
\text { Mouth }\end{array}$ & $\begin{array}{c}\text { Seasonal Purchases through } \\
\text { Instagram DMs }\end{array}$ \\
\hline $\begin{array}{c}\text { Only Social } \\
\text { Media + Web }\end{array}$ & $\mathrm{X}$ & $3 \%$ & Quality & $\begin{array}{c}\text { Word of } \\
\text { Mouth } \\
\text { Word of }\end{array}$ & $\begin{array}{c}\text { Not enough exposure online } \\
\text { Trying to build Digital } \\
\text { presence }\end{array}$ \\
\hline Social Media \\
+ Web +
\end{tabular}

\section{Egyptian Designers Interview Questions:}

1. Do you sell online?

2. Do you have a store front?

3. Do you have an e-commerce website?

4. What is the main reason for selling your products online?

5. On average how many products do you sell monthly?

6. What are the main reasons of returns of your products?

7. Main reasons of return on a scale of 1-10 how to returns? (quantifiable) 
APPENDIX C:

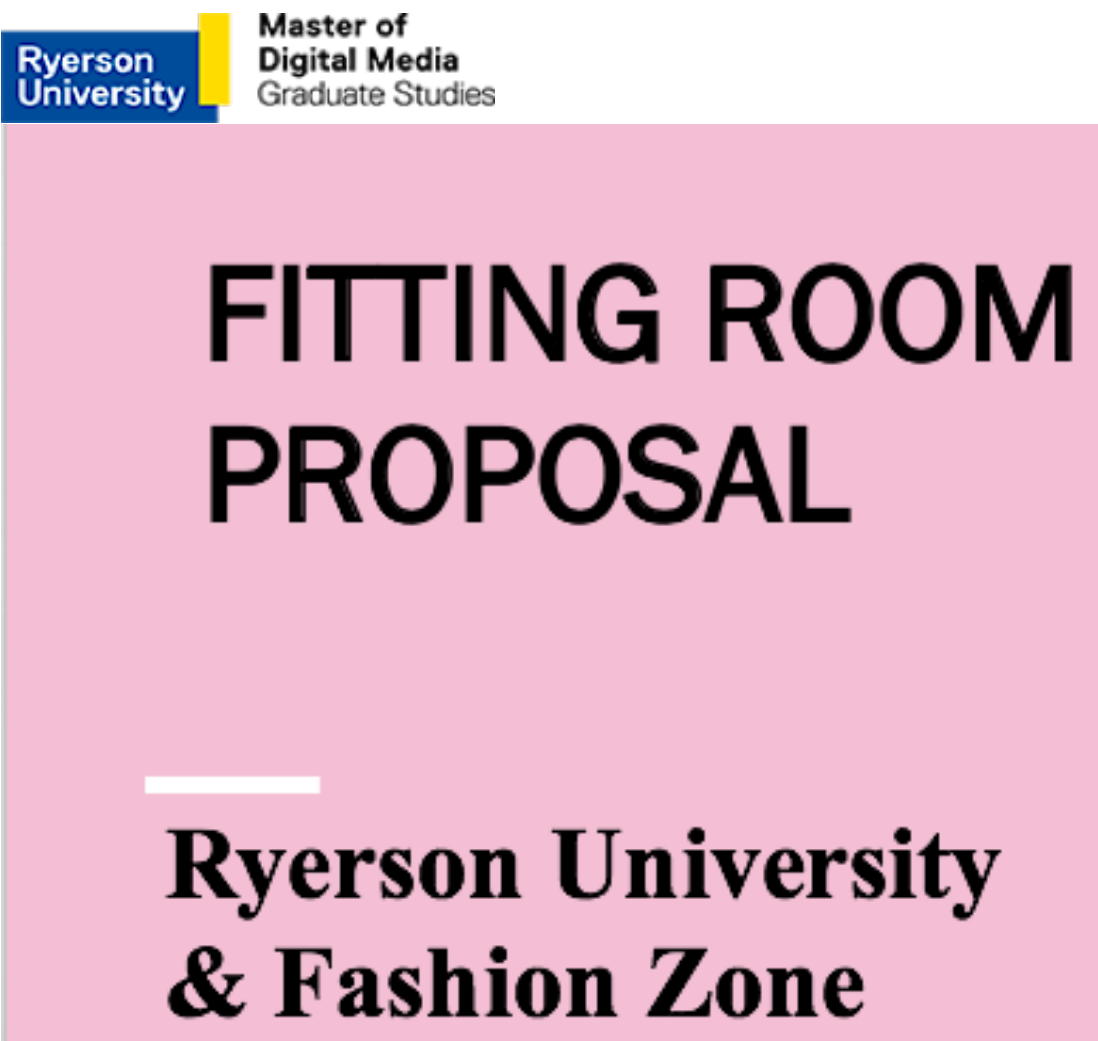

Master of Digital Media

Toronto, Canada 


\section{OVERVIEW}

This project is for official research purposes for students studying at Ryerson University in the Digital Media program in collaboration with Virtual Outfits LLC. We are studying the technology used to enhance the online retail space in Canada. The purpose of this research is to focus on the effectiveness of virtual fitting rooms to augment sales for retailers. The experiment would involve using a demo by Virtual Outfits to certain retailers here in Canada and measuring the click rate.

\section{METRICS THAT WILL BE MEASURED}

Virtual Outfits LLC, would be participating in this research experiment as the best virtual fitting room service solution in the online retail space. Factors that will be validated are the following:

- Virtual Fitting Rooms driving more traffic to products.

- Decrease Returns for designers

- Ultimately providing a better shopping experience for customers.

\section{EXPERIMENT DETAILS}

This experiment will be covered over the duration of a month through a series of A\&B Testing. Six different designers will be showcasing two of their products. Each product will be promoted through a social media post. A post will be displayed with and without the virtual fitting room solution. The number of clicks and time spent using the solution will be measured. The 10 Top selling products will be advertised with the avatar virtual fitting room solution and 2 will be normal Instagram posts about the product. This will convey the effectiveness of the virtual fitting room.

Ryerson

University
Master of Digital Media Graduate Studies 
APPENDIX D:

\section{Early Adopters Survey \\ Enhancing the Online Shopping Experience Survey}

*Results based on 50 respondents

1. How often do you buy products online?
a. Once A week
b. 2-3 Times a Week
c. Once a month (scored highest)
d. Not at all often

2. What type of products do you mostly buy online?
a. Clothes (scored highest)
b. Jewellery
c. Handbags
d. Footwear
e. Other: please specify

3. Would you rather buy from brands that are local to your city or mainstream commercial?
a. Yes, I'd buy from Local Brands (scored highest)
b. No, I'd buy from Mainstream Brands

4. Which are your favourite stores to shop from?
a. ASOS
b. Cult GAIA
c. Neta Porter
d. Missguided
e. Boohoo
f. Amazon (scored highest)
g. Other: please specify

5. What do you hate the most about shopping for clothes online?
a. Quality isn't as expected (scored highest)
b. Clothes doesn't fit
c. Delivery takes so long
d. Other: please specify

6. How comfortable are you buying products online from a company you know?
a. Extremely comfortable
b. Quite comfortable (scored highest)
c. Moderately comfortable
d. Slightly comfortable
e. Not at all comfortable 
7. How confident are you that your payment information is kept secure when you are buying products online?
a. Extremely confident
b. Quite confident (scored highest)
c. Moderately confident
d. Slightly confident
e. Not at all confident

8. What do you think would help you while online shopping?
a. Recommended size assistant based on brands you buy
b. Stylist Assistant
c. Virtual Model that shows you your outfit based on personal body measurements (scored highest)

9. How often do privacy concerns prevent you from buying products online?
a. Always
b. Most of the Time
c. About half of the time
d. Once in a while (scored highest)
e. Never

10. Which payment method do you use most often when buying products online?
a. Credit Card
b. Debit Card
c. PayPal
d. Cash on Delivery (scored highest) 


\section{References}

Ann Marie Fiore, Hyun-Jeong Jin, (2003) "Influence of image interactivity on approach responses towards an online retailer", Internet Research, Vol. 13 Issue: 1, pp.3848, https://doi-org.ezproxy.lib.ryerson.ca/10.1108/10662240310458369

Ashdown, S., Calhoun, E., \& Lyman-Clarke, L. (2009). Virtual Fit of Apparel on the Internet: Current Technology and Future Needs. Handbook of Research in Mass Customization and Personalization,731-748. doi:10.1142/9789814280280_00388

Beck, Marie, and Dominique Crié. (2018) "I Virtually Try It ... I Want It! Virtual Fitting Room: A Tool to Increase On-Line and off-Line Exploratory Behavior, Patronage and Purchase Intentions." Journal of Retailing and Consumer Services, vol. 40, pp. 279-286., doi:10.1016/j.jretconser.2016.08.006.

Dimoka, Angelika and Pavlo, Paul. (2008) "Understanding and Mitigating Product Uncertainty in Online Auction Marketplaces" Alfred Sloan foundation Industry Studies. Retrieved from: https://pdfs.semanticscholar.org/c17a/df1fafba52dfe1df71ea01180c9d705d82bc.pdf

Dey, A., \& Sandor, C. (2014). Lessons learned: Evaluating visualizations for occluded objects in handheld augmented reality. International Journal of Human - Computer Studies, 72(10-11), 704-716. doi:10.1016/j.ijhcs.2014.04.001

El-Din, M. A. (2017, January 22). ICT sector tops state's fastest growing economic sectors. Retrieved October 15, 2017, from https://dailynewsegypt.com/2017/01/22/611703/

Fiore, A.M., Kim, J., Lee, H.H., 2005b. Effect of image interactivity technology on consumer responses toward the online retailer. Journal of Interactive Marketing 19 (3), 38-53.

Finn, Gavin. "Why Augmented Reality and Virtual Reality Will Be Important for Your Business." Entrepreneur. September 12, 2017. Accessed August 09, 2018. https://www.entrepreneur.com/article/300071.

Gehrke, D., Turban, D., 1999. Determinants of successful website design: relative importance and recommendations for effectiveness. In: Proceedings of the 32nd Hawaii International Conference on SystemSciences, pp. 1-8.

Hodgson, Camilla. A Retail Startup That Allows People to Try on Clothes Digitally Just Got a $£ 10$ Million Boost. 9 July 2017, uk.businessinsider.com/metail-retail-startup-gets-10million-boost-virtual-fitting-room-2017-7.

Kiseol Yang, Allison P. Young, (2009) "The effects of customized site features on internet apparel shopping", Journal of Fashion Marketing and Management: An International Journal, Vol. 13 Issue: 1, pp.128-139, https://doi.org/10.1108/13612020910939923 
Kuo, L. (2017, January 23). Startup investment is making a comeback in North Africa. Retrieved October 18, 2017, from https://qz.com/892524/startup-investment-is-making-a-comeback-innorth-africa/.

Li, H., Daugherty, T., Biocca, F., 2003. The role of virtual experience in consumer learning. Journal of Consumer Psychology 13 (4),395-407

Liu, L., Wang, R., Su, Z. et al. Multimedia Tools Apple (2014) 71: 411. https://doiorg.ezproxy.lib.ryerson.ca/10.1007/s11042-013-1437-5

Mcilvaine, Heather. (2018, April 11) Embracing body diversity, Asos invests in virtual fit technology. Retrieved from https://internetretailing.com.au/embracing-body-diversity-asosinvests-virtual-fit-technolog

N. Huang and G. Qin, "A study of online virtual fitting room adoption based on UTAUT," 2011 International Conference on E-Business and E-Government (ICEE), Shanghai, China, 2011, pp. 1-4.Retrieved from http://ieeexplore.ieee.org/stamp/stamp.jsp?tp=\&arnumber=5881681\&isnumber=587664 9

Papadopoulou, P. Virtual Reality (2007) “ Applying virtual reality for trust-building ecommerce environments”11: 107. https://doi.org/10.1007/s10055-006-0059-X

Protopsaltou D., Luible C., Arevalo M., Magnenat-Thalmann N. (2002) A body and Garment Creation Method for an Internet Based Virtual Fitting Room. In: Vince J., Earnshaw R. (eds) Advances in Modelling, Animation and Rendering. Springer, London

Swinyard, W. R., \& Smith, S. M. (2003). Why people (don't) shop online: A lifestyle study of the internet consumer. Psychology and Marketing, 20(7), 567-597. doi:10.1002/mar.10087

The Economist. "Startups in the Arab World" (2017, January 12). Retrieved October 17, 2017, from https://www.economist.com/news/middle-east-and-africa/21714335-arab-entrepreneurscould-help-many-regions-problems-too-many

Raffat, Shaimaa. (2017, August 16). Startups in Middle East need investments worth \$50m in 2017. Retrieved October 17, 2017, from https://dailynewsegypt.com/2017/08/16/startupsmiddle-east-need-investments-worth-50m-2017/.

Yang, K., \& Young, A. P. (2009). The effects of customized site features on internet apparel shopping. Journal of Fashion Marketing and Management: An International Journal, 13(1), 128-139. doi:10.1108/13612020910939923

Wakefield, R. L., Wakefield, K. L., Baker, J., \& Wang, L. C. (2011). How website socialness leads to website use. European Journal of Information Systems, 20(1), 118-132. doi:http://dx.doi.org.ezproxy.lib.ryerson.ca/10.1057/ejis.2010.47 
Warner, M. (2002). Publics and Counterpublics. Public Culture 14(1), 49-90. Duke University Press. Retrieved October 17, 2017, from Project MUSE database. 